\title{
Heat Capacities at High Temperatures of Uranium, Uranium Trichloride, and Uranium Tetrachloride
}

\author{
By Defoe C. Ginnings and Robert J. Corruccini
}

\begin{abstract}
The enthalpies referred to $0^{\circ} \mathrm{C}$ of uranium in the range $0^{\circ}$ to $900^{\circ} \mathrm{C}$, of uranium trichloride in the range $0^{\circ}$ to $725^{\circ} \mathrm{C}$, and of uranium tetrachloride in the range $0^{\circ}$ to $425^{\circ} \mathrm{C}$, have been determined using the "drop" method with an ice calorimeter. Derived values of entropy referred to $0^{\circ} \mathrm{C}$ and specific heat are given. The samples were of high purity. Two firstorder transformations of uranium were observed and the heats of transition calculated from the experimental data. No evidence of first- or second-order transitions in the chlorides was found.
\end{abstract}

\section{Introduction}

This research was undertaken as a part of a program sponsored by the Manhattan District, U. S. Army Corps of Engineers. A portion of the information given in this paper will appear in Division VIII of the Manhattan Project Technical Series. The following report has been declassified by the Atomic Energy Commission.

\section{Method and Apparatus}

The method and apparatus have been described previously. ${ }^{2}$ In brief, the method consisted in heating the sample in a furnace to a known temperature and dropping it into an ice calorimeter that measured the heat evolved in cooling the sample to $0^{\circ} \mathrm{C}$. The calorimeter was calibrated electrically. The sample was sealed in a Nichrome-5 capsule having a screw cap and gold gasket. The heat capacity of the empty capsule and the heat lost by the container during the drop were accounted for by "blank" experiments made with the empty capsule. The temperature of the sample in the furnace was measured by a platinum platinum-rhodium thermocouple that had been calibrated at the National Bureau of Standards.

\footnotetext{
${ }^{1}$ D. C. Ginningss and R. J. Corruccini, J. Research N. B. S. 38, 583 (1947) RP1796.

2 D. C. Ginnings and R. J. Corruccini, J. Research N. B. S. 38, 593 (1947) R P1797.
}

\section{Materials}

\section{Uranium}

The uranium sample, furnished by H. E. Cleaves of the National Bureau of Standards, was in the form of rods having a diameter of $1 / 8 \mathrm{in}$. A spectroscopic analysis of a clean sample of uranium taken from the same batch showed impurities of 0.03 percent to 0.04 percent, including carbon, 0.015 percent; hydrogen, 0.0005 percent; nitrogen, 0.003 percent; and oxygen, 0.002 percent. These impurities were the most significant in computing the correction for impurity to be applied to the enthalpy.

\section{Uranium Trichloride}

The uranium trichloride sample was obtained from E. C. Evers of Brown University and was of the highest obtainable purity. It was prepared from sublimed uranium tetrachloride by reduction with hydrogen and was received in the form of a crystalline powder in a sealed glass bottle, which was kept in a desiccator. The following chemical analysis was received with the sample: $\mathrm{U}+\mathrm{Cl}=99.97$ percent; atom ratio $\mathrm{Cl} / \mathrm{U}=3.001$; material insoluble in water $=0.13$ percent, calculated as $\mathrm{UO}_{2}$. A portion of the sample was transferred to the Nichrome capsule in a drybox containing $\mathrm{P}_{2} \mathrm{O}_{5}$, helium was admitted and the 
capsule was sealed. At the time of the transfer, another portion of the sample was taken for further analysis. The analysis (performed under the direction of J. J. Tregoning of the National Bureau of Standards) gave $\mathrm{U}+\mathrm{Cl}=99.50$ percent, atom ratio $\mathrm{Cl} / \mathrm{U}=2.999$, material insoluble in water $=0.55$ percent, calculated as $\mathrm{UO}_{2}$. A spectrographic analysis performed at the same time indicated a total of about 0.08 percent miscellaneous metal impurities (mainly $\mathrm{Ca}, 0.01 \%$; Fe, $0.013 \% ; \mathrm{Mg}, 0.01 \%$; $\mathrm{Na}, 0.02 \%$; and $\mathrm{Si}, 0.006$ $\%$ and confirmed the belief that the principal metallic constituent of the water-insoluble material was uranium.

\section{Uranium Tetrachloride}

The uranium tetrachloride was distilled in Pyrex in vacuum from a sample bearing the analysis, $\mathrm{U}+\mathrm{Cl}=99.50$ percent, atom ratio $\mathrm{U} / \mathrm{Cl}=3.997$. A small amount of reddish solid that was more volatile than the uranium tetrachloride was discarded in this process, as well as nonvolatile products such as $\mathrm{UO}_{2}$. (The $\mathrm{UO}_{2}$ would result from contamination of the sample with water, followed by hydrolysis.) Uranium tetrachloride is extremely hygroscopic. At the close of the distillation, the receiver was sealed. It was next opened in a drybox containing $\mathrm{P}_{2} \mathrm{O}_{5}$, the sample pulverized with a steel rod, and a portion transferred to the Nichrome capsule, helium was admitted and the capsule was immediately sealed. Samples taken before and after the filling of the capsule gave essentially identical chemical analyses averaging $\mathrm{U}+\mathrm{Cl}=99.97$ percent, atom ratio $\mathrm{Cl} / \mathrm{U}=4.003$. A spectrographic analysis made at the same time indicated the presence of 0.1 percent of miscellaneous metals (mainly Fe, 0.05 percent; Na, 0.02 percent; Ca, 0.01 percent; $\mathrm{Mg}$, 0.01 percent; $\mathrm{Al}, 0.005$ percent) and 0.1 to 1 percent of $\mathrm{Ni}$. At the completion of the experimental work, the sample was removed from the capsule in the drybox and again analyzed, giving $\mathrm{U}+\mathrm{Cl}=$ 99.64 percent, atom ratio $\mathrm{Cl} / \mathrm{U}=4.023$.

\section{Results}

Table 1 gives the results of the individual experiments. The "apparent" calibration factor ${ }^{3}$ of the ice calorimeter was taken as 64.638 calories per gram of mercury ( $1 \mathrm{cal}=4.1833$ int joule). In

$$
\text { s see footnote } 1 \text {. }
$$

columns 2 and 3 are given the masses of mercury after small corrections have been applied for buoyancy, heat leak, change in level of mercury meniscus, variation in capsule weight, and variation in the amounts of gas and gold contained in the capsule. As these corrections are in most cases so small as to be barely significant, they are not listed separately. They are approximately the same as in a previous report. ${ }^{4}$ The masses at a given temperature are listed in the order in which the experiments were performed, although this is not true of the order in the table as a whole.

\section{Uranium}

The first series of experiments extended up to $756.7^{\circ} \mathrm{C}$, and was made with a sample of uranium that had been pickled in nitric acid to remove the surface film of oxide. The air in the capsule was replaced with helium before sealing. It was found in experiments at $790^{\circ} \mathrm{C}$ that the uranium was attacking the Nichrome capsule. A second series of experiments in the range $723.9^{\circ}$ to $898.6^{\circ} \mathrm{C}$ was then made with a portion of the sample on which a thin protective film of oxide had been formed. In addition, the bottom of the capsule was covered with a layer of $\mathrm{BeO}$ (about $1 \mathrm{~g}$ ) in order to reduce the contact between the uranium and the capsule. There was no evidence of attack with these precautions. The $\mathrm{BeO}$ was kept in the capsule during the blank experiments of the second series.

TABLE 1.-Results of individual experiments

\begin{tabular}{|c|c|c|c|c|c|c|}
\hline \multirow[b]{2}{*}{$\begin{array}{l}\text { Tempera- } \\
\text { ture }\end{array}$} & \multicolumn{3}{|c|}{ Mass of Mercury } & \multicolumn{3}{|c|}{$\left(H-H_{\mathrm{o}}{ }^{\circ} \mathrm{c}\right)$} \\
\hline & $\begin{array}{l}\text { Blank } \\
\text { experi- } \\
\text { ments }\end{array}$ & $\begin{array}{l}\text { Experi- } \\
\text { ments } \\
\text { with } \\
\text { sample }\end{array}$ & Net & $\begin{array}{c}\text { Ob- } \\
\text { served a }\end{array}$ & $\begin{array}{l}\text { Calcu- } \\
\text { lated b }\end{array}$ & $\begin{array}{l}\text { Observed } \\
\text { minus } \\
\text { calculated }\end{array}$ \\
\hline
\end{tabular}

URANIUM, SERIES $A$ (58.7768-GRAM SAMPLE)c

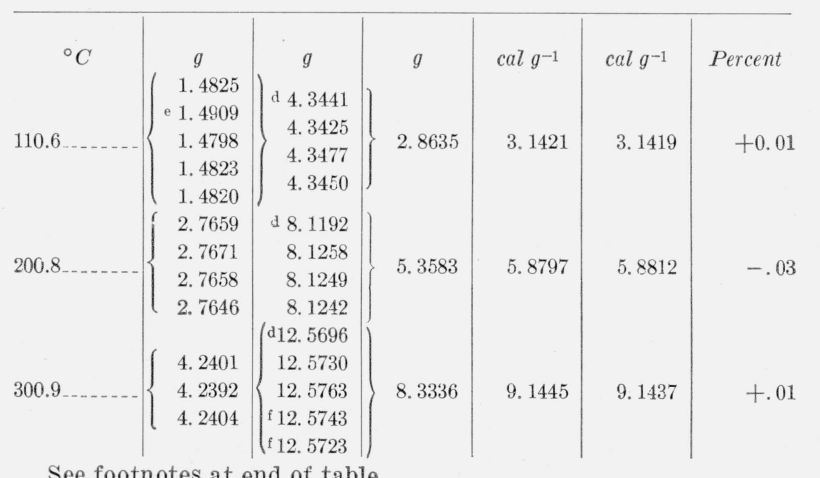

See footnotes at end of table.

4 See footnote 2. 
TABLE 1.-Results of individual experiments-Continued

\begin{tabular}{|c|c|c|c|c|c|c|}
\hline \multirow[b]{2}{*}{$\begin{array}{l}\text { Tempera- } \\
\text { ture }\end{array}$} & \multicolumn{3}{|c|}{ Mass of Mercury } & \multicolumn{3}{|c|}{$\left(H-H_{0} \circ_{c}\right)$} \\
\hline & $\begin{array}{l}\text { Blank } \\
\text { experi- } \\
\text { ments }\end{array}$ & $\begin{array}{l}\text { Experi- } \\
\text { ments } \\
\text { with } \\
\text { sample }\end{array}$ & Net & $\begin{array}{c}\text { Ob- } \\
\text { served a }\end{array}$ & $\begin{array}{l}\text { Calcu- } \\
\text { lated b }\end{array}$ & $\begin{array}{l}\text { Observed } \\
\text { minus } \\
\text { calculated }\end{array}$ \\
\hline
\end{tabular}

URANIUM, SERIES $A$ (58.7768-GRAM SAMPLE) e-Continued

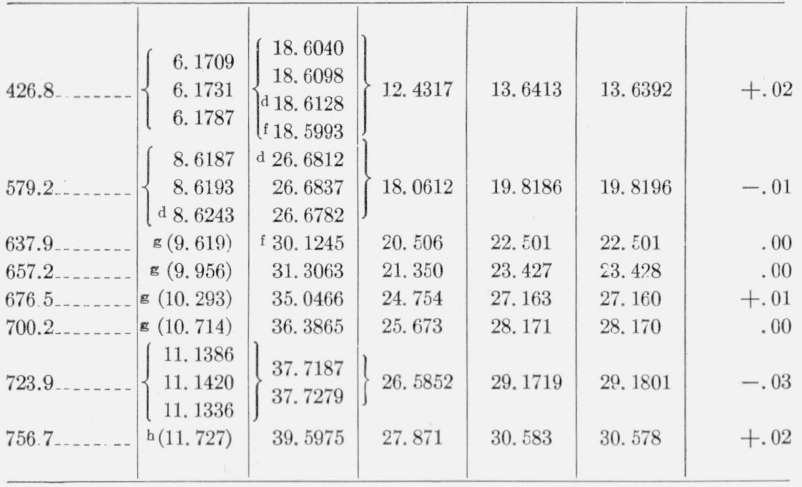

URANIUM, SERIES $B$ (40.4032-GRAM SAMPLE) c

\begin{tabular}{|c|c|c|c|c|c|c|}
\hline 723.9 & $\left\{\begin{array}{l}15.6009 \\
15.6041\end{array}\right.$ & $\begin{array}{r}\text { d } 33.9078 \\
33.8997\end{array}$ & 18. 2999 & 29.172 & 29. 180 & -0.03 \\
\hline $789.2 \ldots \ldots$ & 17. 2651 & 40. 2712 & 23.0061 & 36.674 & 36.652 & +.06 \\
\hline $807.7 \ldots$ & 17. 7361 & 41. 1632 & 23. 4271 & 37.345 & 37. 363 & -.05 \\
\hline 853.4 & $\left\{\begin{array}{r}\mathrm{d} 18.9062 \\
18.9184\end{array}\right.$ & 43. 4475 & 24.5321 & 39. 106 & 39.119 & -.03 \\
\hline $898.6 \ldots$ & 20.0762 & 45. 7132 & 25.6370 & 40.866 & 40.856 & +.02 \\
\hline
\end{tabular}

URANIUM TRICHLORIDE (16.4069-GRAM SAMPLE) c

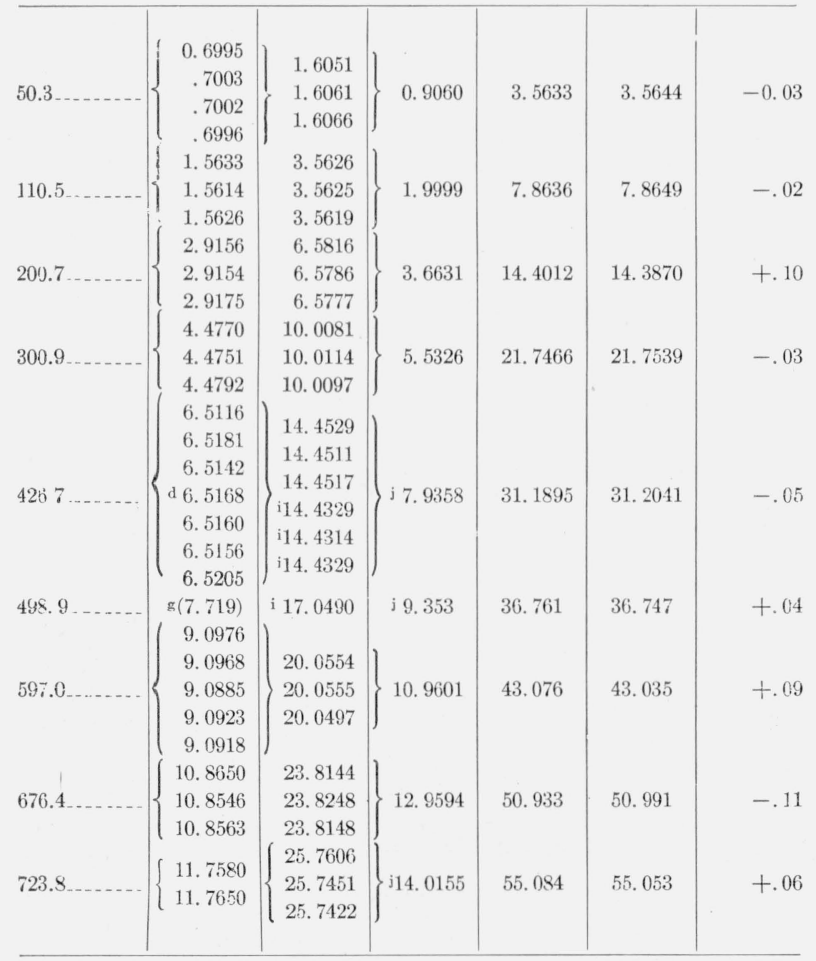

See footnotes at end of table.
TABLE 1.-Results of individual experiments-Continued

\begin{tabular}{|c|c|c|c|c|c|c|}
\hline \multirow[b]{2}{*}{$\begin{array}{l}\text { Tempera- } \\
\text { ture }\end{array}$} & \multicolumn{3}{|c|}{ Mass of Mercury } & \multicolumn{3}{|c|}{$\left(H-H_{0^{\circ}} \mathrm{c}\right)$} \\
\hline & $\begin{array}{l}\text { Blank } \\
\text { experi- } \\
\text { ments }\end{array}$ & $\begin{array}{l}\text { Experi- } \\
\text { ments } \\
\text { with } \\
\text { sample }\end{array}$ & Net & $\begin{array}{c}\text { Ob- } \\
\text { served a }\end{array}$ & $\begin{array}{l}\text { Calcu- } \\
\text { lated b }\end{array}$ & $\begin{array}{l}\text { Observed } \\
\text { minus } \\
\text { calculated }\end{array}$ \\
\hline
\end{tabular}

URANIUM TETRACHLORIDE (16.8451 GRAM SAMPLE) •

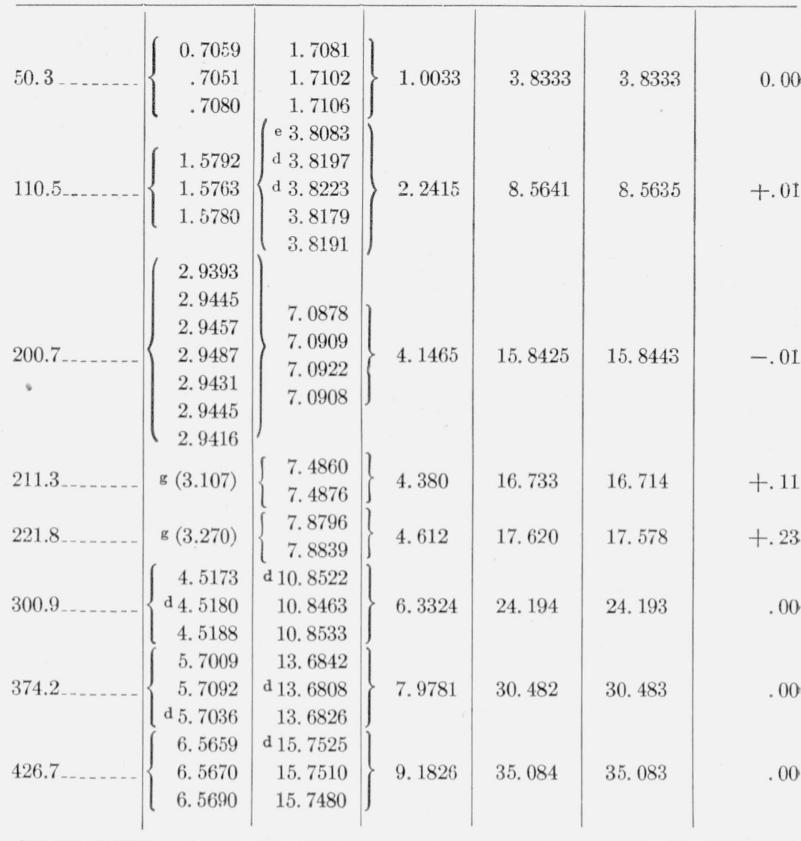

a Corrected for impurity.

b In the cases of $\alpha$-uranium and $\mathrm{UCl}_{3}$, these data were obtained by interpolation in the smoothed tables of enthalpy before rounding off and with allowance for curvature. In the cases of $\beta$ and $\gamma$-uranium and $\mathrm{UCl}_{4}$, these values were calculated from equations that were fitted to the observed data See text.

c Corrected for buoyancy.

d Weighted less due to unsteady heat leak.

- Discarded according to Chauvenet criterion.

f These experiments followed experiments at temperatures above the first transition.

$\mathrm{g}$ Interpolated.

b Extrapolated.

i These experiments followed those at $723.8^{\circ} \mathrm{C}$, and are considered to be affected by corrosion of the capsule by the $\mathrm{UCl}_{3}$, at that temperature.

i Corrected for effect of corrosion of the capsule. See text.

The second series gave a result at $723.9^{\circ} \mathrm{C}$ that was 0.14 percent higher than that obtained in the first series. This difference could have been caused by only one part in 10,000 (by weight) of oxygen, present as $\mathrm{U}_{3} \mathrm{O}_{8}$. Accordingly, the difference was attributed to the oxide film on the sample used in the second series and all results obtained in this series were corrected by -0.14 percent. In addition, an estimated correction of -0.21 percent for the impurities shown in the spectrographic analysis was applied to all results with uranium. 
Tarle 2.-Enthalpy, specific heat, and entropy at even temperature intervals $\left(1 \mathrm{cal}=4.1833\right.$ int $\left.j ; 0^{\circ} \mathrm{C}=273.16^{\circ} \mathrm{K}\right)-$

\begin{tabular}{|c|c|c|c|}
\hline$t$ & $H-H_{0}^{\circ} \mathrm{C}$ & $C_{p}$ & $S-S_{0}{ }^{\circ} \mathrm{C}$ \\
\hline \multicolumn{4}{|c|}{ URANIUM } \\
\hline$\left({ }^{\circ} \mathrm{C}\right)$ & cal g-1 & cal $g^{-1} \mathrm{deg}^{-1} C$ & cal $g^{-1} \operatorname{deg}^{-1} K$ \\
\hline 0 & 0 & 0.0275 & 0 \\
\hline 50 & 1.393 & .0283 & .00469 \\
\hline 100 & 2.831 & .02919 & .008819 \\
\hline 150 & 4. 317 & .03022 & .012552 \\
\hline 200 & 5.856 & .03135 & .015988 \\
\hline 250 & 7.453 & .03257 & .019197 \\
\hline $300 \ldots \ldots$ & 9.113 & .03388 & .022228 \\
\hline $350 \ldots$ & 10.841 & .03529 & .025119 \\
\hline 400 & 12.642 & .03681 & .027900 \\
\hline $450 \ldots \ldots$ & 14.521 & .03846 & .030595 \\
\hline 500 & 16. 486 & .04031 & .033226 \\
\hline $550 \ldots$ & 18. 552 & .04253 & .035819 \\
\hline $600 \ldots \ldots$ & 20.750 & .04521 & .038403 \\
\hline $650 \ldots \ldots$ & 23.080 & .04818 & .041001 \\
\hline $668(\alpha)$ & 23.965 & .0193 & .04194 \\
\hline ITransition & $\Delta H=2.83$ & (n) & $\Delta S=0.00301]$ \\
\hline $668(\beta)$ & 26. 797 & 0.04262 & 0.04495 \\
\hline 700 & 28. 161 & .04262 & .04637 \\
\hline 750 & 30.292 & .04262 & .04851 \\
\hline $774(\beta)$ & 31.316 & .04262 & .04950 \\
\hline [Transition & $\Delta H=45.5$ & - n..... & $\Delta S=0.00454]$ \\
\hline $774(\gamma) \ldots \ldots$ & 36.067 & .03843 & .05404 \\
\hline 800 & 37.067 & .03843 & 05498 \\
\hline 850 & 38.989 & .03843 & .05673 \\
\hline $900 \ldots$ & 40. 910 & .03843 & .05840 \\
\hline
\end{tabular}

URANIUM TRICHLORIDE

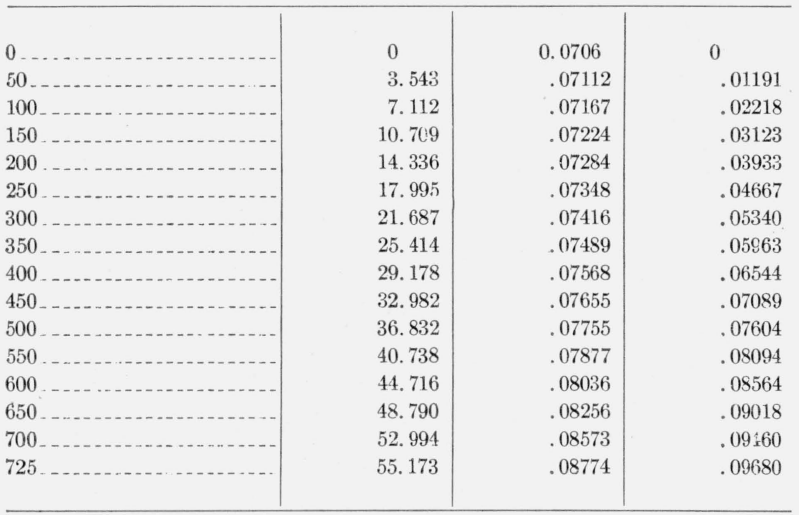

URANIUM TETRACHLORIDE

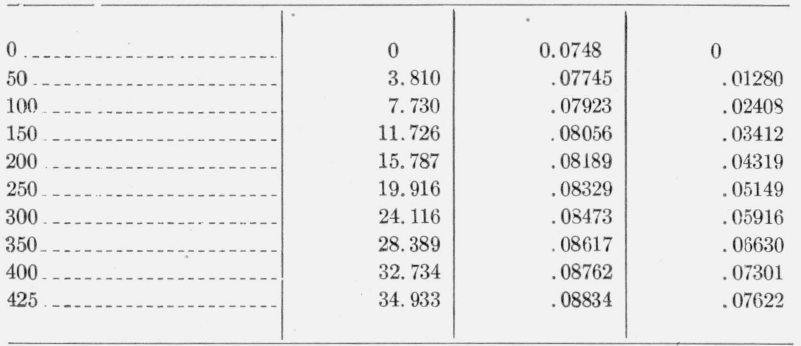

The two transitions of uranium were clear-cut with no evidence of pretransition effects. No attempt was made to determine closely the tem- peratures of the transitions. For the purpose of calculating the heats of transition, the values $668^{\circ}$ and $774^{\circ} \mathrm{C}$ were used for the transition temperatures. These were estimated from measurements by Dahl and Van Dusen ${ }^{5}$ of the variation of electrical resistance of uranium with temperature and may be in error by a few degrees.

The results at temperatures below the first transition cannot be closely represented by a simple equation. Enthalpies at even temperature intervals were obtained by graphical interpolation and smoothed by adjustment of differences. The specific heat, $C_{p}$, and entropy referred to $0^{\circ} \mathrm{C}, S-$ $S_{0}{ }^{\circ}$ c, were derived graphically from the enthalpies in this temperature range. The resuits are given in table 2.

At temperatures above the first transition but below the second, the observed values of enthalpy in calories per gram, referred to the $\alpha$-form at $0^{\circ} \mathrm{C}$, are represented within 0.03 percent by the equation (fitted by the method of least squares)

$$
H-H_{0}{ }^{\circ} \mathrm{C}=-1.675+0.04262 t(\beta \text {-form }),
$$

where $t$ is in $\operatorname{deg} \mathrm{C}$. Correspondingly,

$$
C_{p}=0.04262(\beta \text {-form })
$$

$S-S_{0}{ }^{\circ} C=\int_{668}^{T}\left[C_{p(\beta)} / T\right] d T+\left[S_{(\beta) 668^{\circ}}-S_{(\alpha) 0^{\circ} C}\right](\beta$-form $)$

$$
S-S_{0}{ }^{\circ} \mathrm{C}=0.098144 \log _{10} T-0.24690(\beta \text {-form }),
$$

where $T$ is in degrees Kelrin, taking $0^{\circ} \mathrm{C}$ as $273.16^{\circ} \mathrm{K}$.

At temperatures above the second transition, the observed values of enthalpy referred to the $\alpha$-form are represented within 0.06 percent by the equation (least squares)

$$
H-H_{0}{ }^{\circ} \mathrm{C}=6.326+0.03843 t(\gamma-\text { form })
$$

Correspondingly, $C_{p}=0.03843(\gamma$-form)

$$
\begin{aligned}
& S-S_{0}{ }^{\circ} C=\int_{774}^{T}\left[C_{p(\gamma)} / T\right] d T+\left[S_{(\gamma) z 74}{ }^{\circ}-S_{(\alpha) 0}{ }^{\circ} C\right](\gamma \text {-form }) \\
& S-S_{0}{ }^{\circ}=0.088481 \log _{10} T-0.21318 \text { ( } \gamma \text {-form). }
\end{aligned}
$$

Values calculated for even temperature intervals from the above equations are given in table 2 .

The regularity of the data for the $\beta$ and $\gamma$ forms would seem to indicate that the two transformations were reversible under the experimental con-

\footnotetext{
${ }^{5}$ Andrew I. Dahl and Milton S. VanDusen, J. Research NBS 39, 53 (1947)
} RP1813. 
ditions. Certain experiments in the $\alpha$ range (noted in table 1) that were performed after the sample had been heated above the first transition show no significant abnormality.

It may be interesting to note that both the $\beta$ and $\gamma$ forms have not only constant values of $C_{p}$, but also have constant values of temperature coefficient of electrical resistance. ${ }^{6}$ Also, the difference between the values of $C_{p}$ for the two forms is 1.00 calories per degree-gram atom, which, within experimental error, is the value of $R / 2$, where $R$ is the universal gas constant. In the absence of complete information as to the crystal structures of the two forms, it is not possible to ascribe significance to the latter fact.

\section{Uranium Trichloride}

As it was expected that the capsule would be attacked to a slight extent by the $\mathrm{UCl}_{3}$, the effect of this upon the enthalpy was tested by making a group of three experiments at $426.7^{\circ} \mathrm{C}$ at the beginning and a similar group at the end of the series of experiments with the sample. The average of the results of the final group was 0.14 percent lower than the average of the first group. No consistent variation was noted within either group alone, the maximum deviation from the mean of a group being 0.007 percent. On the other hand the results of the three experiments at $723.8^{\circ} \mathrm{C}$ showed a definite downward trend with the order performed over a range of 0.07 percent. It was assumed, therefore, that corrosion of the capsule at the higher temperatures had indeed affected the results. As there was no clear-cut evidence of a trend with time in the experiments at $579.0^{\circ}$ and $676.4^{\circ} \mathrm{C}$, it was assumed that all the corrosion had occurred during the experiments at $723.8^{\circ} \mathrm{C}$. With some arbitrariness, the mass of mercury that would have been obtained in an experiment at $723.8^{\circ} \mathrm{C}$ in the absence of corrosion was taken to be 0.14 percent higher than the last result in the group at that temperature. The result at $498.9^{\circ} \mathrm{C}$ which was the only other one obtained following the experiments at $723.8^{\circ} \mathrm{C}$ was also corrected by +0.14 percent. At the close of the experiments, after removal of the sample from the capsule, it was found that the latter had lost $17.1 \mathrm{mg}$, or 0.2 percent, of its mass as a result of the corrosion.

${ }^{6}$ See footnote 5 .
The correction for the impurities in the sample at the start of the experiments was somewhat uncertain because of the inconsistency of the two chemical analyses, the uncertainty as to the state of chemical combination of the spectrographically determined impurities, and the fact that the most probable forms (oxides or chlorides) of the latter have specific heats about three times that of $\mathrm{UCl}_{3}$, which magnifies their effect upon the results. Fortunately, $\mathrm{UO}_{2}$ has nearly the same specific heat (within 20 percent) as $\mathrm{UCl}_{3}$, which reduces the uncertainty resulting from the variance in the amount of water-insoluble material found in the sample. Making reasonable assumptions with regard to the spectrographically determined impurities and employing the enthalpy data of Moore and Kelly ${ }^{7}$ for $\mathrm{UO}_{2}$, led to a total correction for impurities that ranged from -0.17 percent at $50.3^{\circ} \mathrm{C}$ to -0.24 percent at and above $426.7^{\circ} \mathrm{C}$.

A smooth curve was drawn through a plot of $\left(H-H_{0}{ }^{\circ}{ }_{C}\right)_{o b s} / t$ versus $t$, values were read off at even temperature intervals and smoothed by adjustment of differences. The specific heat, $C_{p}=(\partial H / \partial T)_{p}$, was calculated from the smoothed values of enthalpy by the method of Rutledge ${ }^{8}$ and $S-S_{0}{ }^{\circ} C=\int_{0}^{\mathrm{t}}\left(C_{p} / T\right) d t$ was calculated by using Simpson's Rule.

The results are given in table 2 .

\section{Uranium Tetrachloride}

The effect of possible reaction between the capsule and $\mathrm{UCl}_{4}$ was tested by making a pair of experiments at $200.7^{\circ} \mathrm{C}$ early in the series of experiments with sample and a similar pair at the end of the series. The average of the second pair was only $2.1 \mathrm{mg}$, or 0.03 percent higher than the average of the first pair, which is as good agreement as could have been expected had the experiments been performed at the same time. Accordingly, no correction for corrosion of the capsule was applied. At the close of the series of experiments it was found that the capsule had lost $6.8 \mathrm{mg}$ owing to corrosion, or only about one-third as much as for the $\mathrm{UCl}_{3}$.

The correction for the impurities in the sample was subject to the same difficulties as for $\mathrm{UCl}_{3}$. In addition, the chemical analyses were discordant in that they appeared to indicate a loss of 0.32 per-

${ }^{7}$ G. E. Moore and K. K. Kelley, J. Am. Chem. Soc. 69, 2105 (1947).

8 G. Rutledge, Phys. Rev. 40, 262 (1932). 
cent of uranium between the first and second analyses, the percentage of $\mathrm{Cl}$ remaining constant. Actually, there is every reason to believe that no detectable change in the sample occurred. The only reasonable alteration of the sample to expect would have been the loss of $\mathrm{Cl}$ (as $\mathrm{HCl}$ resulting from moisture absorption and hydrolysis) rather than the loss of uranium. Making reasonable assumptions with regard to the impurities led to a correction of -0.43 percent.

The mean specific heat, $\left(H-H_{0^{\circ} \mathrm{C}}\right)_{o b s} / t$, was found to be practically a linear function of temperature above $200^{\circ} \mathrm{C}$. The following equation was fitted by trial and error (gram basis):

$$
\begin{aligned}
H-H_{0}{ }^{\circ} \mathrm{C}= & 0.07605 t+1.446 \times 10^{-5} t^{2}- \\
& 0.00122 t \times 10^{-0.00516 t-0.0000278 t 2} .
\end{aligned}
$$

Correspondingly,

$$
\begin{aligned}
C_{p}= & 0.07605+2.891 \times 10^{-5} t- \\
& 0.00122\left[1-2.3\left(0.00516 t+0.0000556 t^{2}\right)\right] \times \\
& 10^{-0.00516 t-0.0000278 t 2} .
\end{aligned}
$$

Values were calculated from these equations at even temperature intervals and the entropy, $S-S_{0^{\circ} \mathrm{C}}$, obtained by Simpson's rule. The results are given in table 2 .

\section{Discussion}

\section{Accuracy}

The instrumental error is about the same as in some previous measurements, where a more detailed discussion is given. ${ }^{9}$ The error involved in measuring the temperature of the sample in the furnace contributes the major part of this uncertainty to which a value of about 0.2 percent may be assigned. In addition, the corrections for impurity have uncertainties of perhaps one-half their own magnitudes or 0.1 percent in the cases of uranium and $\mathrm{UCl}_{3}$ and 0.2 percent for $\mathrm{UCl}_{4}$. Taking all errors into account, the authors believe the corrected and smoothed enthalpies to be within 0.2 to 0.3 percent of the true values, except for the values at $50^{\circ} \mathrm{C}$. At and below this temperature, the relative instrumental error is larger.

The specific heat and entropy possess a small additional uncertainty resulting from the fact that the derivative of a quantity can never be known as accurately as the quantity itself in the absence of

\footnotetext{
${ }^{9}$ Sce footnote 2 .
}

a rigid mathematical formulation. This uncertainty becomes larger at the ends of the experimental ranges of the data, except for the hightemperature end of the uranium and $\mathrm{UCl}_{4}$ data, where linear representation of the enthalpy makes accurate differentiation possible. The heats of transition are accurate to perhaps 1 percent.

\section{Comparison with other work}

In none of the five known investigations presenting data comparable to those of this report was a correction applied for impurities, although only one of these authors ${ }^{10}$ claimed to have a sample that was pure within analytical error. The heat capacities of uranium and its compounds are exceptionally sensitive to the presence of impurities, because the specific heats of the latter are usually several times as large as that of the pure uranium or uranium compound. As the samples used in the present investigation were of high purity, and as a correction was applied in each case to account for the presence of impurity, it was to be expected that the results of the other investigations, with the exception noted, would be the higher, calorimetric errors being left out of account.

In order to permit a condensed presentation of the data for comparison purposes, values of $C_{p}$ and $\left(H-H_{0^{\circ} \mathrm{C}}\right) / t$ in calories per degree-mole divided by the number of atoms per molecule are given in figure 1 for all three substances.

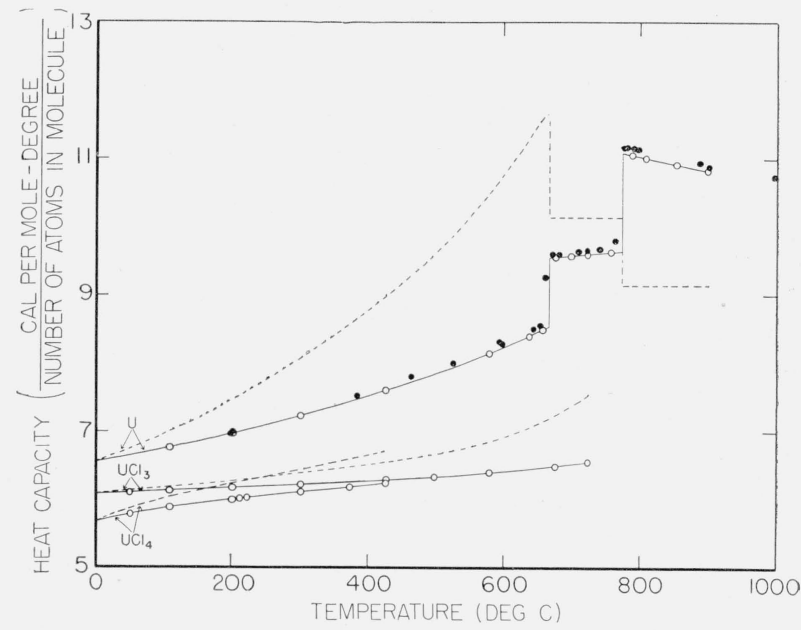

FIGURE 1. True and mean heat capacities.

$H-H_{0}{ }^{\circ} \mathrm{C} / t: \mathrm{O}, \mathrm{NBS}$ (observed): — $\longrightarrow$, NBS (smoothed): Kelley. $\quad C_{p}$ : ......, NBS (derived).

10 C. Zimmerman, Liebigs Ann. Chem. 216, 14 (1883). 
(a) Uranium

The specific heat of a sample of unstated purity has been determined from low temperatures up to $27^{\circ} \mathrm{C}$ by E. A. Long, W. M. Jones, and J. Gordon ${ }^{11}$ in the laboratory of W. F. Giauque at the University of California. Their values are lower than those of this investigation, the difference decreasing from 1.0 percent at $27^{\circ} \mathrm{C}$ to 0.3 percent at $0^{\circ} \mathrm{C}$. These authors appear to claim an accuracy of 0.2 percent in this range. The specific-heat curve from the present investigation, if extrapolated downward, would become tangent to the above authors' results at about $-30^{\circ} \mathrm{C}$.

The enthalpy (referred to $25^{\circ} \mathrm{C}$ ) of a 99.71-percent-pure sample has been measured at temperatures up to $1,000^{\circ} \mathrm{C}$ by Moore and Kelley. ${ }^{12}$ These data were converted to the same basis as the enthalpy data of this paper by addition of the quantity, $H_{25^{\circ} \mathrm{C}}-H_{0^{\circ} \mathrm{C}}=0.688 \mathrm{cal} \mathrm{g}^{-1}$, taken from the report of Long, Jones, and Gordon. ${ }^{13}$ The converted enthalpy data of Moore and Kelley were found to average 0.8 percent higher than those of the present investigation. The comparison is shown in figure 1, where the enthalpies have been converted to mean specific heats, $(H-$ $\left.H_{0^{\circ} \mathrm{C}}\right)_{l} t$, in order to give a representation that is more sensitive to the small differences between the two sets of data. For the $\beta$-form, the data of Moore and Kelley give $C_{p}=0.04360 \mathrm{cal} \mathrm{g}^{-1} \mathrm{deg}^{-1} \mathrm{C}$, that is, 2.3 percent higher than the value in this investigation. For the $\gamma$-form, Moore and Kelley's results give $C_{p}=0.03822 \mathrm{cal} \mathrm{g}^{-1} \mathrm{deg}^{-1} \mathrm{C}$, which is 0.5 percent lower than the value in this investigation. Comparison of the values of $C_{p}$ for the $\alpha$-form is not as informative, as Moore and Kelley's values must be obtained from an equation for the enthalpy that does not represent the data as closely as did the equations given by them for the higher forms.

The mean specific heat between $0^{\circ}$ and $98.7^{\circ} \mathrm{C}$ was measured by Zimmerman, ${ }^{14}$ who obtained $0.0277 \mathrm{cal} \mathrm{g}^{-1} \mathrm{deg}^{-1} \mathrm{C}$ as the mean of three experiments covering a spread of 1.5 percent. His sample reportedly was 100.0 percent pure. Blumcke ${ }^{15}$ later disputed the interpretation of the data

\footnotetext{
11 Classified report submitted to the Manhattan District, U. S. Army Corps of Engineers

12 See footnote 7 .

13 See footnote 11 .

14 See footnote 10

15 A. Blumcke, Ann. Physik, (III) 24, 263 (1855).
}

in these experiments and calculated the result to be 0.0280 . These values are, respectively, 2 percent and 1 percent below the result of this investigation.

\section{(b) Uranium Trichloride}

The specific heat of a sample of unknown purity has been determined from low temperatures to $107^{\circ} \mathrm{C}$ by W. J. Ferguson and J. L. Prather ${ }^{16}$ at the National Bureau of Standards. They give $C_{p}=$ $0.0713 \mathrm{cal} \mathrm{g}^{-1} \mathrm{deg}^{-1} \mathrm{C}$ at $0^{\circ} \mathrm{C}$, which is 1 percent higher than the result of the present investigation. They report $C_{p}=103 \mathrm{cal} \mathrm{mole}^{-1} \mathrm{deg}^{-1} \mathrm{C}$ (equivalent to $0.0715 \mathrm{cal} \mathrm{g}^{-1} \mathrm{deg}^{-1} \mathrm{C}$ ) for all temperatures from $17^{\circ}$ to $107^{\circ} \mathrm{C}$. This result is identical with those of this investigation from $53^{\circ}$ to $107^{\circ} \mathrm{C}$ within the uncertainty of the number 103, or 0.5 percent. Correspondingly, the mean specific heat between $0^{\circ}$ and $100^{\circ} \mathrm{C}$ is calculated to be $0.07147 \mathrm{cal} \mathrm{g}^{-1}$ $\mathrm{deg}^{-1} \mathrm{C}$, or 0.5 percent higher than the result of this investigation.

\section{(c) Uranium Tetrachloride}

The specific heat of a sample of unspecified purity has been determined from low temperatures to $82^{\circ} \mathrm{C}$ by W. J. Ferguson, J. L. Prather, and R. B. Scott. ${ }^{17}$ Their results above $0{ }^{\circ} \mathrm{C}$ are 0.3 to 0.6 percent higher than those of this investigation.

The experiments at $211.3^{\circ}$ and $221.8^{\circ} \mathrm{C}$ in this investigation were performed with the intent of disclosing the second-order transition reported found at $211^{\circ}$ by N. W. Gregory. ${ }^{18}$ Such a transition would appear as a sudden change in slope of the plot of mean specific heat versus temperature. The deviations of the results at these temperatures from the function chosen to represent the data were, indeed, much larger than for the other results (see table 1). However, in view of the facts that only two experiments with the sample were made at each of these temperatures, and that values for blank experiments were obtained by interpolation rather than by direct measurement, it appears that the deviations $(0.11$ and 0.23 percent, respectively) of these results from the curve are not significantly greater than experimental error would allow. It can only be concluded that if this transition exists, it is quite small and occurs above $222^{\circ} \mathrm{C}$ for a pure sample.

\footnotetext{
16 Classified report submitted to the Manhattan District, U. S. Army Corps of Engineers.

17 See footnote 16

18 See footnote 16 .
} 


\section{Summary}

The enthalpies of uranium, $\mathrm{UCl}_{3}$ and $\mathrm{UCl}_{4}$ at high temperatures have been determined. Values of specific heat and entropy have been derived. Values of the heats of transition of two first-order transformations in uranium are given. No evidence was found of first- or second-order transitions in $\mathrm{UCl}_{3}$ or $\mathrm{UCl}_{4}$.

Washington, May 23, 1947. 